\title{
Lignocellulosic: Non-Conventional Low Cost Biosorbent for the Elution of Coomassie Brilliant Blue (R-250)
}

\author{
Hajira Tahir ${ }^{1} \&$ Uroos Alam ${ }^{1}$ \\ ${ }^{1}$ Department of Chemistry, University of Karachi, Pakistan \\ Correspondence: Hajira Tahir, Department of Chemistry, University of Karachi, Pakistan. Tel: 92-333-362-1470. \\ E-mail: hajirat@uok.edu.pk
}

Received: March 7, 2014 Accepted: April 16, 2014 Online Published: April 22, 2014

doi:10.5539/ijc.v6n2p56 URL: http://dx.doi.org/10.5539/ijc.v6n2p56

\begin{abstract}
The objective of present research work focuses on the utilization of lignocellulosic material like coir pith for the removal of dye. Coir pith is an inexpensive and ecofriendly biosorbent that is utilized for the removal of Coomassie Brilliant Blue (R-250) dye from waste streams by adsorption method. The adsorption experiments were preceded considering the dose of adsorbent, stay time, concentration of dye, $\mathrm{pH}_{(\mathrm{pzc})}$ point zero charge activity by $\mathrm{pH}$ drift method. Adsorption isotherms for monolayer and multilayered adsorption were applied and the values of constants like Langmuir $\left(\mathrm{K}_{\mathrm{L}}\right)$, Freundlich $\left(\mathrm{K}_{\mathrm{f}}\right)$, and Dubinin-Radushkevich $\left(\mathrm{E}_{\mathrm{s}}\right)$ were estimated by applying standard graphical method to assess the adsorption capacity of coir pith raw (CPR) and its modified carbonized form (CPC). The most appropriate model for the equilibrium process of CPR-CBB(R-250) and CPC-CBB(R-250) were the Freundlich and D-R isotherm model. A complete thermodynamic evaluation was conducted by estimating the values of enthalpy $\left(\Delta \mathrm{H}^{\circ}\right)$, free energy $\left(\Delta \mathrm{G}^{\circ}\right)$, and entropy $\left(\Delta \mathrm{S}^{\circ}\right)$ of the system. The surface morphology of CPR and CPC was evaluated by Scanning Electron Microscopy (SEM) and Fourier transforms infrared (FTIR) techniques. The results showed that with the rise in temperature of the system the dye adsorption rate was also increased. Thermodynamic analysis revealed that the adsorption process was endothermic and spontaneous in nature. Kinetics of dye removal was also investigated and results revealed that $\mathrm{CPR}$ and $\mathrm{CPC}$ follows second order rate constant. The maximum removal capacity of $\mathrm{CBB}(\mathrm{R}-250)$ with $\mathrm{CPR}$ was found to be $70 \%$ and of CPC is $99 \%$.
\end{abstract}

Keywords: adsorption thermodynamics, coomassie brilliant blue (R-250), FTIR, lignocellulosic material, $\mathrm{pH}_{(\mathrm{pzc})}$, SEM, triphenylmethane dyes

\section{Introduction}

Water is one of the natural limited reservoirs that is utilized at every step of different industrial processes. The water from industries is full of colorful as well as colorless chemical additives. The expulsion of this type of polluted water acts as an added factor to environment pollution due to the acidic $\mathrm{pH}$, colored pigments, de-foamers, bleaches, detergents, equalizers and many other additives. Dyes are stable, recalcitrant, colorants and even potentially carcinogenic and toxic (Vijayaraghavan \& Yun, 2008; Wu \& Tseng, 2008). Dyes are made of conjugated molecules that give them their respective color. The color depends on the number of conjugated bonds. Decolorization involves breaking of the conjugated bonds. The discharge of dyes in open water streams is worrying for both toxicological and esthetical reasons (Pignon et al., 2003). It is estimated that more than 100,000 commercially available dyes with over $7 \times 10^{5}$ tons of dyestuff produced annually (Ravikumar et al., 2005). The presence of the dyes even at a very low concentration is highly observable and undesirable. (Rangabhashiyam et al., 2014; Gautama et al., 2014)

Biosorption processes are particularly suitable for the treatment of solutions containing dilute (toxic) dye concentration (Aksu, 2005; Aksu \& Tezer, 2005; Fu \& Viraraghavan, 2002; Robinson et al., 2001). Biosorption is one of the physiochemical process that take place without providing energy. The removal of impurities from water streams is dependent upon on the cellular structure of the sorbent. Bioaccumulation is an active metabolic process driven by energy from a living organism and requires respiration. Since biosorption is determined by equilibrium, it is largely influenced by $\mathrm{pH}$, the concentration of biomass and the interaction between different metallic ions (Valesquez et al., 2009). Adsorbents are usually in the form of spherical pallets, rods, moldings or monoliths with hydrodynamic diameters. They must have high abrasion resistance, high 
thermal stability and small pore diameters, which results in higher exposed surface area and hence high surface capacity for adsorption (Magdy \& Daifullah, 1998; Namasivayam et al., 2001). They should be cheap, easily available and disposable without regeneration. These materials are derived from natural resources, plant wastes or industrial by-products as peat, wood, barley and rice husk, etc. Most of them are cellulose-based and can be used without any previous thermal or chemical treatment (Ferrero, 2007). Adsorbents containing high levels of cellulose irreversibly adsorb basic dyes through columbic attraction since negative surface charge is acquired by cellulose on contact with water (Robinson et al., 2002; Robinson, Chandaran, \& Nigam, 2002; Annadurai et al., 2002; Sun \& Yan, 2003; Garg et al., 2003; EL Zawahry \& Kamel, 2004; Batzias \& Sidiras, 2004; Ozacar \& Sengil, 2005; Bousher et al., 1997; Chial et al., 1993). Activated carbon adsorption is the most popular physio-chemical treatment for the removal of dissolved organics from wastewaters. In general, activated carbons are efficient in the adsorption of both organic and inorganic dyes (Namasivayam \& Kavitha, 2002).

The soil and climatic conditions of coastal areas in Sindh and Balochistan offer great opportunities for speedy growth of coconut and oil palm trees. The coconut requires warm climate with temperatures of $22{ }^{\circ} \mathrm{C}$ or higher. Coconut can be grown in wide range of soils. Coconut husk is the meso-carp of coconut and a coconut consists of $33-35 \%$ of husk. Coir dust is rich in lignin and tannins. It is composed of cellulose, furfural, and lignin. The outermost covering of coconut shell that surrounds the coconut is called coir. It consists mainly of fibers, which have traditionally been used to manufacture rope, carpets, doormats, upholstery stuffing, brushes etc. Between these fibers is the corky substance called coir pith or coir dust. Due to the presence of high content of lignin of about $45.84 \%$ and cellulose $43.44 \%$, it is called as lignocellulosic biosorbent. Nowadays coconut husks are used as fuel for coconut processing, as a domestic fuel and as a source of fiber for rope and mats (Tan et al., 2008)

Coomassie Brilliant Blue is one of the triphenylmethane dyes. This class of dyes is organic compounds containing colored cation. The intense color of triphenylmethane dye is because of the conjugated system of alternate double and single bonds. They are highly light resistant and are used chiefly in copying papers, in hectograph and printing inks, and in textile applications for which light fastness is not an important requirement. They are applied by various techniques, but most belong to the basic class, which are adsorbed from solution by silk or wool and have little affinity for cotton (Fox, 1987). The name Coomassie was adopted at the end of the $19^{\text {th }}$ century as a trade name by the Bleckley based dye manufacturer Levinstein Ltd, in marketing a range of acid wool dyes. The original Coomassie dye was developed as a wool dye and named to commemorate the 1896 British occupation of Coomassie (now Kumasi) in Ghana. In Coomassie Blue R-250 ("R" standing for "reddish" and " 250 " being the dye strength indicator). R-250 is typically color invariant. The color of the dye depends on the acidity of the solution. The dye has a red color with an absorption maximum at a wavelength of $470 \mathrm{~nm}$ at lower $\mathrm{pH}$ values. At $\mathrm{pH}=1$ the dye is green with an absorption maximum at $620 \mathrm{~nm}$ while above $\mathrm{pH}$ $=2$ the dye is bright blue with a maximum at $595 \mathrm{~nm}$. At pH 7 the dye has an extinction coefficient of 43,000 $\mathrm{M}^{-1} \mathrm{~cm}^{-1}$ (Azmi et al., 1998).

In this work removal of CBB (R-250) was carried out by utilizing lignocellulosic sorbent CPR and CPC. The results showed that the $\%$ removal capacity increased along with the enhancement of the surface capacity.

\section{Materials and Method}

\subsection{Materials}

Coomassie Brilliant Blue (R-250) was obtained from BDH laboratory Chemicals having color Index 42660. The chemical formula of $\mathrm{CBB}$ is $\mathrm{C}_{45} \mathrm{H}_{44} \mathrm{~N}_{3} \mathrm{NaO}_{7} \mathrm{~S}_{2}$ and its molecular weight is $825.97 \mathrm{~g} / \mathrm{mole}$. It was used as an adsorbate. While Methanol $99.85 \%$ was used to dissolve the dye, as this particular dye is partially soluble in water.

\subsection{Making of Coomassie Brilliant Blue (R-250) Solution}

$\mathrm{CBB}$ is insoluble in cold water and slightly soluble in warm water. It was first dissolved in methanol and then the solution was made up to desired concentration with distilled water. The stock solution of CBB was prepared having concentration of $100 \mathrm{ppm}\left(1.2 \times 10^{-4} \mathrm{~mol} / \mathrm{dm}^{3}\right)$. Maximum wavelength of dye solution was recorded by taking spectrum using double beam spectrophotometer (T80 UV/VIS Spectrophotometer) and it was found to be $591 \mathrm{~nm}$. The prepared stock solution was used for the adsorption and thermodynamic studies. The chemical structure of CBB is shown in Figure 1. 


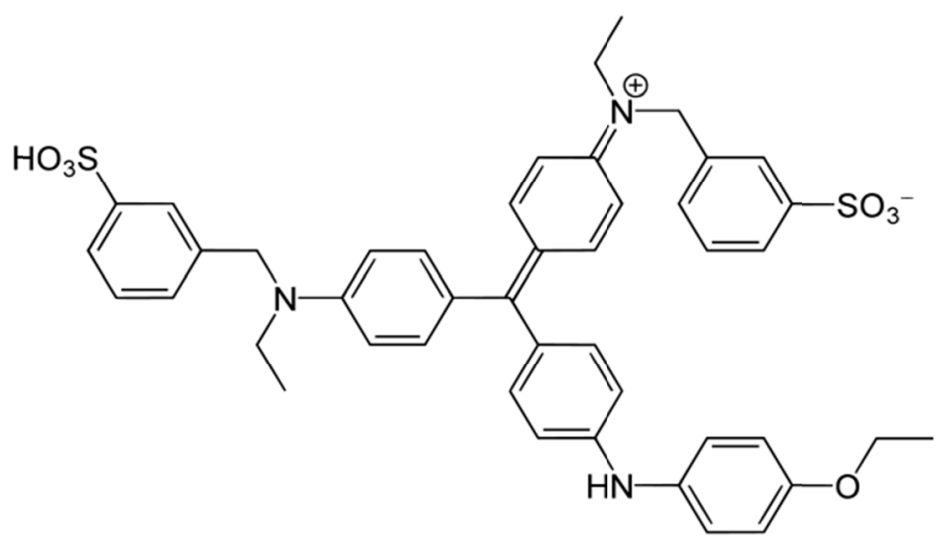

Figure 1. Chemical structure of Coomassie Brilliant Blue (R-250)

\subsection{Preparation of Adsorbent}

Coir pith (CP) was obtained from local coconut seller in Karachi, Pakistan. The waste CP was air dried and ground. The dried $\mathrm{CP}$ powder was sieved up to required mesh size and further experimental techniques were applied by using raw adsorbent.

Further treatment was also done by subjecting CP to carbonization at $600{ }^{\circ} \mathrm{C}$ for $1.5 \mathrm{~h}$ using a muffle furnace. The carbonized material was placed immediately within an airtight container to avoid contact with air.

\section{Group Mode Adsorption Studies}

In order to estimate the feasibility of adsorption, laboratory group mode studies were regulated. A fair contact between adsorbent and dyes were conducted by agitating at $200 \mathrm{rpm}$. After shaking the suspensions were filtered. The residual dye concentration was evaluated by (T80 UV/VIS) spectrophotometer. Parameters which influence the extent of adsorption such as adsorbate concentration, stay time, and dose of adsorbent were investigated.

\subsection{Choice of Appropriate Amount of Adsorbent}

In order to find out the ideal amount of adsorbent at which maximum adsorption takes place, $50 \mathrm{ml}$ of $4.842 \times$ $10^{-5} \mathrm{~mol} / \mathrm{dm}^{3}$. CBB dye solution was taken in a series of Erlenmeyer flasks with different quantity of adsorbent ranging from $0.1,0.2,0.3$, and $0.4 \ldots$ to $1.5 \mathrm{~g}$ of CPR and CPC powder. The solution of dye was placed in shaking incubator (JISCO Shaking Incubator) for $1 \mathrm{hr}$ at $200 \mathrm{rpm}$. The dye solution was separated from adsorbent through filtration and absorbance was noted to find out at which amount the maximum removal was achieved (Boparai et al., 2011).

\subsection{Choice of Appropriate Shaking Time}

The effect of time for the adsorption of CBB (R-250) dye on CPR \& CPC adsorbents was detected. Optimum amount of CPC and CPR ( $0.8 \mathrm{~g})$ was added in respective flasks with $50 \mathrm{ml}$ of optimum concentration of dye solution for different time intervals varying from 10 to $120 \mathrm{~min}$. After particular time period the dye solution was separated from adsorbent and the solution absorbance was noted to determine the maximum adsorption capacity of CPR and CPC at specific time period (Hu et al., 2006).

\subsection{Choice of Appropriate Dye Concentration}

For the determination of ideal concentration of dye, different concentrations of CBB dye were prepared within the range of $2.421 \times 10^{-5}-6.658 \times 10^{-5} \mathrm{~mol} / \mathrm{dm}^{3}$. $50 \mathrm{ml}$ of dye solution of each concentration was placed in respective flask with optimum amount of $\mathrm{CPC}$ and $\mathrm{CPR}(0.8 \mathrm{gm})$ for $1 \mathrm{hr}$ for temperatures ranges from 303 to $318 \pm 2 \mathrm{~K}$. After optimum shaking time period, the dye solution was filtered using Whatman no. 42 filter paper and absorbance was recorded by UV-visible spectrophotometer at $591 \mathrm{~nm}$ to determine the concentration range at which maximum adsorption capacity was achieved. Finally the ideal dye concentration was estimated by graphically (Mylsamy et al., 2012).

$3.4 \mathrm{pH}$ at the Point of Zero Charge $\mathrm{pH}_{(p z c)}$

Point of zero charge for a given surface is the $\mathrm{pH}$ at which the surface has a net neutral charge. The $\mathrm{pH}$ at the point of zero charge $\mathrm{pH}_{(\mathrm{pzc})}$ of $\mathrm{CPR}$ and $\mathrm{CPC}$ was measured by using the $\mathrm{pH}$ drift method. The $\mathrm{pH}$ of 0.005 
$\mathrm{mol} / \mathrm{dm}^{3} \mathrm{NaCl}$ solutions was adjusted between 1.5 to 12.5 by adding required amount of $0.5 \mathrm{M} \mathrm{HCl}$ or $\mathrm{NaOH}$. The $0.8 \mathrm{gm}$ of adsorbent was added in $60 \mathrm{~mL}$ of solution in Erlenmeyer flask and placed in covered condition for $48 \mathrm{hrs}$. After specific time period the $\mathrm{pH}$ was noted by using PHS-3BW Microprocessor $\mathrm{pH}$ Meter.

\subsection{Photocatalytic Degradation}

Thin film coated was prepared by mixing $1.5 \mathrm{~g}$ of titanium dioxide and $1 \mathrm{~g}$ part of cement. Semisolid mass was prepared with de-ionized water. A thin coating of titanium dioxide paste was applied over the inner surface of the petri dish and allowed to dry at room temperature for 24 hours. The next day $100 \mathrm{ml}$ Coomassie Brilliant Blue (R-250) dye solution of $4.82 \times 10^{-5} \mathrm{M}$ was taken in the petri dish and exposed to direct sunlight. The photocatalytic degradation of Coomassie Brilliant Blue R-250 was observed after each 10 minutes by taking few $\mathrm{ml}$ of dye solution and the absorbance was measured to determine the \%degradation of dye (Hema, 2008).

\section{Results and Discussion}

In recent research work, the removal of CBB (R-250) has been examined onto CPR and CPC. The adsorption, effect of point zero charge, thermodynamic and rate order kinetics were examined by series of adsorption experiments considering the ideal quantity of CPR and CPC and stay time.

\subsection{Effect of Amount of Adsorption Parameter}

The dose of adsorbent is an exclusive parameter as it quantifies the capacity of an adsorbent for the initial dye concentration. The adsorption of CBB (R-250) dye onto CPR and CPC was examined by changing the amount of adsorbent from 0.1 to $1.5 \mathrm{~g}$. The results showed that the percentage removal capacity of CBB (R-250) increased with the increase quantity of CPR and CPC. The maximum adsorption was observed at 0.8 gm of adsorbent. This is because of the availability of more adsorption sites. The amount of adsorbent at time $t, K_{D}(\mathrm{~mol} / \mathrm{g})$, was calculated using the following formula:

$$
\mathrm{K}_{\mathrm{D}}=\left(\mathrm{C}_{\mathrm{i}}-\mathrm{C}_{\mathrm{f}}\right) \mathrm{V} / \mathrm{W}
$$

Where $C_{f}\left(\mathrm{~mol} / \mathrm{dm}^{3}\right)$ is the final dye concentration at any time, $C_{i}\left(\mathrm{~mol} / \mathrm{dm}^{3}\right)$ is the initial concentration of dye in the solution, Vis the volume of the solution $(\mathrm{ml})$ and $\mathrm{W}$ is the mass of the adsorbent $(\mathrm{g})$.

The amount of equilibrium adsorption, $\mathrm{X} / \mathrm{m}(\mathrm{mol} / \mathrm{g})$ was calculated as:

$$
\mathrm{X} / \mathrm{m}=\left(\mathrm{C}_{\mathrm{i}}-\mathrm{C}_{\mathrm{e}}\right) \mathrm{V} / \mathrm{W}
$$

Where $\mathrm{C}_{\mathrm{i}}$ and $\mathrm{Ce}\left(\mathrm{mol} / \mathrm{dm}^{3}\right)$ are the initial concentrations of dye at equilibrium. The \% removal of dye was calculated as follows:

$$
\% \text { Removal }=\left(\mathrm{C}_{\mathrm{i}}-\mathrm{C}_{\mathrm{f}}\right) / \mathrm{C}_{\mathrm{i}} \times 100
$$

The $\mathrm{K}_{\mathrm{D}}$ and \% removal values for the maximum adsorption of CPR \& CPC were found to be 62.5 and $100 \%$ respectively as shown in Figure 2.

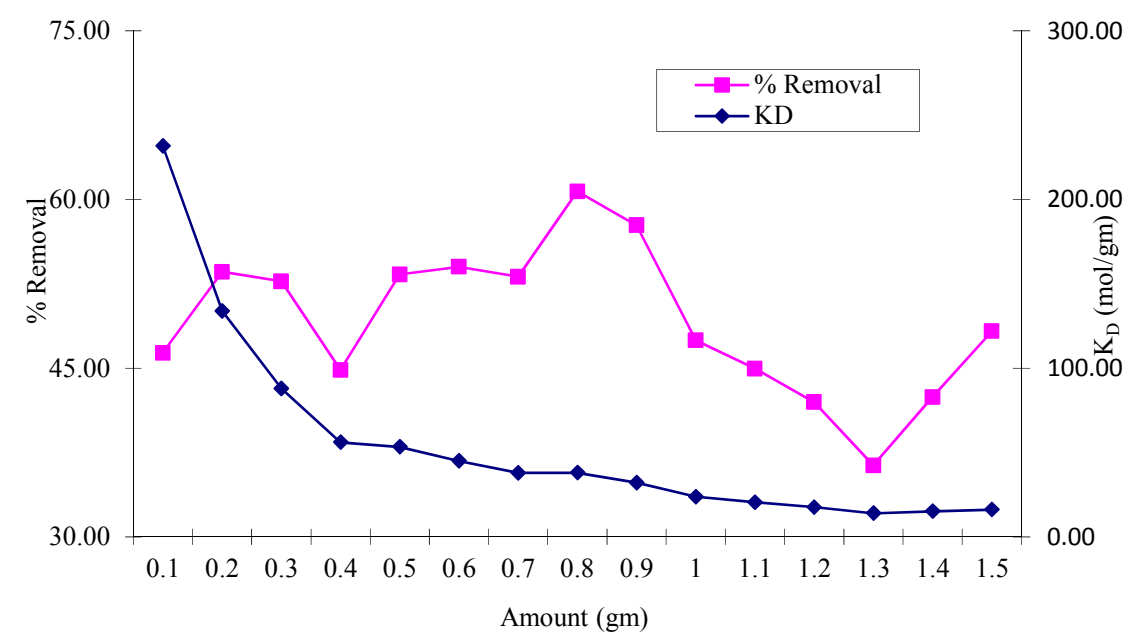

Figure 2(a). Graph of optimization of amount of CPR 


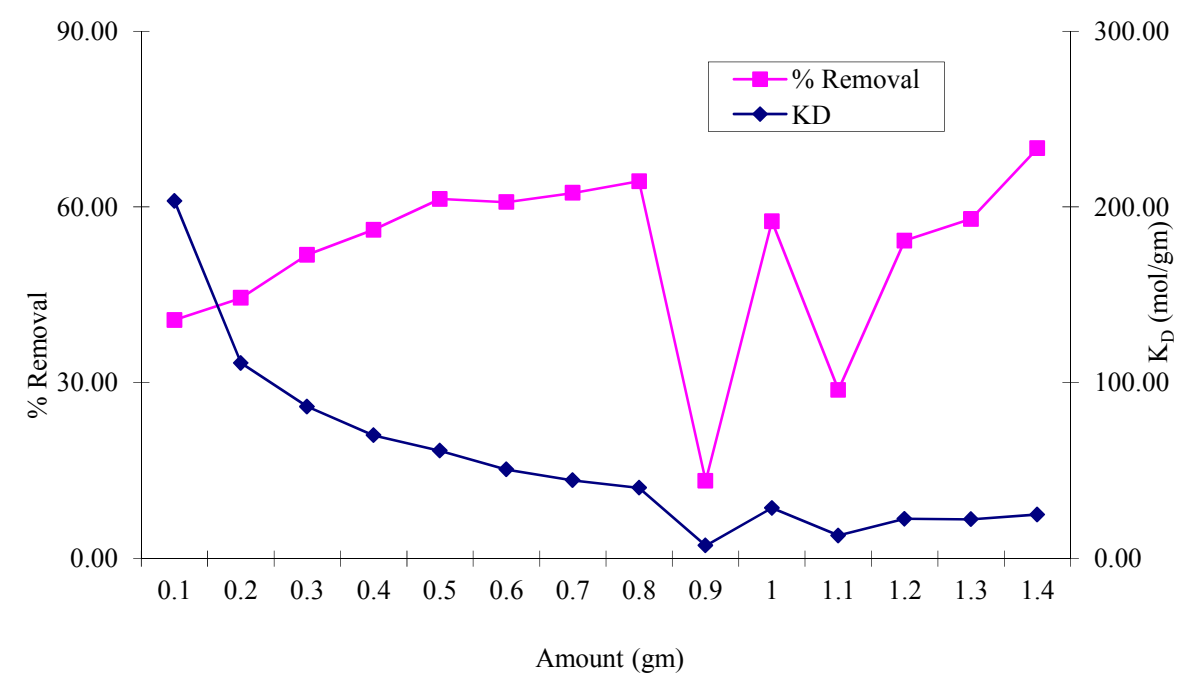

Figure 2(b). Graph of optimization of amount of CPC

\subsection{Effect of Shaking Time}

The results revealed that there was a sharp increase in dye adsorption with the increasing time factor and finally highest adsorption capacity of CBB (R-250) on CPR was $73.0 \%$ at 50 minutes and for CPC $100 \%$ at 90 minutes.

\subsection{Effect of Concentration of Adsorbate}

The effect of concentration of dye by using optimum amount of CPR and CPC was studied. The concentration of CBB (R-250) was in range from $2.421 \times 10^{-5}$ to $6.653 \times 10^{-5} \mathrm{M}$. The optimum concentration of adsorbate for CPR was $4.237 \times 10^{-5} \mathrm{M}$ and for CPC $2.421 \times 10^{-5} \mathrm{M}$.

\subsection{Effect of Temperature}

For estimating the effect of temperature for the removal of CBB (R-250) through CPR, the temperatures were varied from 303 to $323 \mathrm{~K}( \pm 2 \mathrm{~K})$. The results showed that with the increase in temperature the adsorption of CPR increased upto $70 \%$.

With CPC, the temperature was varied from $293 \mathrm{~K}$ to $308 \mathrm{~K}( \pm 2 \mathrm{~K})$. The results showed that the adsorbing capacity of CPC increased up to $99.99 \%$ with the increase in temperature.

\subsection{Adsorption Isotherm}

Adsorption isotherm is an invaluable curve describing the phenomenon governing the retention or mobility of a substance from the aqueous porous media on aquatic environments to a solid-phase at a constant temperature and pH (Limousin et al., 2007; Ncibi, 2008). Typically, the mathematical correlation, which constitutes an important role towards the modeling analysis, operational design and applicable practice of the adsorption systems, is usually depicted by graphically expressing the solid-phase against its residual concentration (Langmuir, 1916).

The CBB (R-250) concentration was varied from 20 to 60 ppm by keeping all other parameters constants. By using the adsorbed quantity of $\mathrm{CBB}(\mathrm{R}-250)$ and equilibrium concentration $(\mathrm{Ce})$, the adsorption isotherms of CBB (R-250) on CPR and CPC were evaluated by drawing a graph between extent of adsorption $(\log q)$ and equilibrium concentration $\log C e$. The adsorption data was fitted in adsorption model like Langmuir, Freundlich and Dubinin-Radushkevich adsorption isotherms.

\subsubsection{Langmuir Adsorption Isotherm}

Langmuir adsorption isotherm is in use from many years to express and compare the adsorption capacity of different biosorbents (Vijayaragahavan et al., 2006). This empirical model focuses monolayer adsorption (the adsorbed layer is one molecule in thickness), with adsorption can only occur at a definite localized sites, that are identical and equivalent, with no lateral interaction and stearic hindrance between the adsorbed molecules, even on adjacent sites (Demirbas et al., 2008).

Graphically, it is characterized by a plateau, an equilibrium saturation point where once a molecule occupies a site, no further adsorption can take place (Senthilkumar et al., 2010; Tahir et al., 2009). Moreover, Langmuir 
theory has related rapid decrease of the intermolecular attractive forces to the rise of distance.

By applying Langmuir isotherm, the values of Langmuir constants were evaluated as shown below:

$$
\mathrm{Ce} / \mathrm{X} / \mathrm{m}=\left(1 / \mathrm{KV}_{\mathrm{m}}\right)+\mathrm{Ce} / \mathrm{V}_{\mathrm{m}}
$$

Where Ce is equilibrium concentration $\left(\right.$ moles $\left./ \mathrm{dm}^{3}\right), V_{m}$ is monolayer sorption capacity, $\mathrm{X} / \mathrm{m}$ is maximum possible amount of dye that can be adsorbed per unit dry weight of sorbent (mol/gm), $\mathrm{K}$ is Langmuir empirical constant, also called binding constant. From the slope $1 / \mathrm{V}_{\mathrm{m}}$ and intercepts $1 / \mathrm{K} \cdot \mathrm{V}_{\mathrm{m}}$ was evaluated (UCUN, 2011) as shown in Table 1.

Table 1. Langmuir parameter for the adsorption of CBB (R-250) onto CPR \& CPC:

\begin{tabular}{|c|c|c|c|c|c|c|c|}
\hline \multicolumn{4}{|c|}{ CPR } & \multicolumn{4}{|c|}{ CPC } \\
\hline $\begin{array}{c}\text { Temperature } \\
\left({ }^{\circ} \mathrm{C}\right)\end{array}$ & $\mathbf{V}_{\mathbf{m}}$ & $\mathbf{K}_{\mathbf{L}}$ & $\mathbf{R}^{2}$ & $\begin{array}{c}\text { Temperature } \\
\left({ }^{\circ} \mathrm{C}\right)\end{array}$ & $\mathbf{V}_{\mathbf{m}}$ & $\mathbf{K}_{\mathbf{L}}$ & $\mathbf{R}^{2}$ \\
\hline 303 & 0.00282 & 4.60 & 0.808 & 293 & 0.0141 & $1.6 * 10^{-2}$ & 0.086 \\
\hline 308 & 0.00175 & 5.15 & 0.75 & 298 & -0.0003 & $-2.1 * 10^{-3}$ & 0.189 \\
\hline 313 & 0.00277 & 5.42 & 0.762 & 303 & 0.0006 & $7.09 * 10^{-3}$ & 0.090 \\
\hline 318 & 0.0175 & 1.66 & 0.036 & 308 & -0.00002 & $-8.6^{*} 10^{-6}$ & 0.368 \\
\hline
\end{tabular}

\subsubsection{Freundlich Adsorption Isotherm}

The mathematical expression for Freundlich isotherm is represented as;

$$
\log \mathrm{X} / \mathrm{m}=\log \mathrm{K}+1 / \mathrm{n} \log \mathrm{Ce}
$$

Where "Ce" is the dye equilibrium concentration in solution $\left(\mathrm{mg} / \mathrm{dm}^{3}\right)$. The values of $\mathrm{K}_{\mathrm{f}}$ and $1 / \mathrm{n}$ were obtained by plotting graph between $\log \mathrm{X} / \mathrm{m}$ and $\log \mathrm{Ce}$ (Lagergen, 1898). The Freundlich isotherm describes the disordernes of the adsorbent surface. It considers multilayer adsorption with a heterogeneous energetic distribution of active sites accompanied by interactions between adsorbed molecules. Constant $\mathrm{K}_{\mathrm{f}}$ is Freundlich constant that indicates the adsorption capacity where $1 / \mathrm{n}$ is the attribute of adsorption. As the temperature increases the constants $\mathrm{K}_{\mathrm{f}}$ and $\mathrm{n}$ change to reflect the empirical observation that the quantity adsorbed rises. The value of $\mathrm{n}$ for CPR lies between 1 and 10 indicates a favorable sorption process. Whereas the values of $\mathrm{n}$ for $\mathrm{CPC}$ at $293 \mathrm{~K}$ and $298 \mathrm{~K}$ are between 1 and 10 confirming the advantageous sorption process while at $303 \mathrm{~K}$ and $308 \mathrm{~K}$ the values of $\mathrm{n}$ are less than 1 shows feasible adsorption process. The results are compiled in Table 2 and Figure 3 (a \& b).

\begin{tabular}{|c|c|c|c|c|c|c|c|}
\hline \multicolumn{4}{|c|}{ CPR } & \multicolumn{4}{|c|}{ СPC } \\
\hline $\begin{array}{c}\text { Temperature } \\
\left({ }^{\circ} \mathrm{C}\right)\end{array}$ & $\mathbf{n}$ & $\mathbf{K}_{\mathbf{f}}$ & $\mathbf{R}^{2}$ & $\begin{array}{c}\text { Temperature } \\
\left({ }^{\circ} \mathrm{C}\right)\end{array}$ & $\mathbf{n}$ & $\mathbf{K}_{\mathbf{f}}$ & $\mathbf{R}^{2}$ \\
\hline 303 & 1.75 & 0.476 & 0.92 & 293 & 1.32 & 0.738 & 0.649 \\
\hline 308 & 3.15 & 0.0301 & 0.61 & 298 & 1.65 & 0.121 & 0.947 \\
\hline 313 & 1.59 & 0.8016 & 0.87 & 303 & 0.56 & 34700 & 0.923 \\
\hline 318 & 1.08 & 15.10 & 0.93 & 308 & 0.43 & 102000 & 0.757 \\
\hline
\end{tabular}

Table 2. Freundlich parameter for the adsorption of CBB (R-250) onto CPR \& CPC 


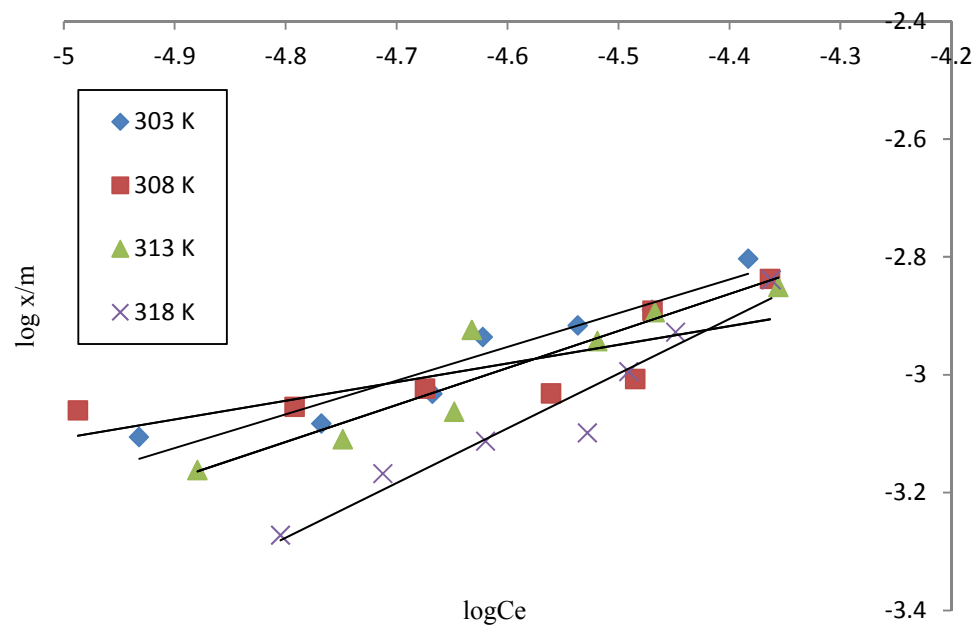

Figure 3(a). Freundlich isotherm graph for the adsorption of CBB (R-250) onto CPR

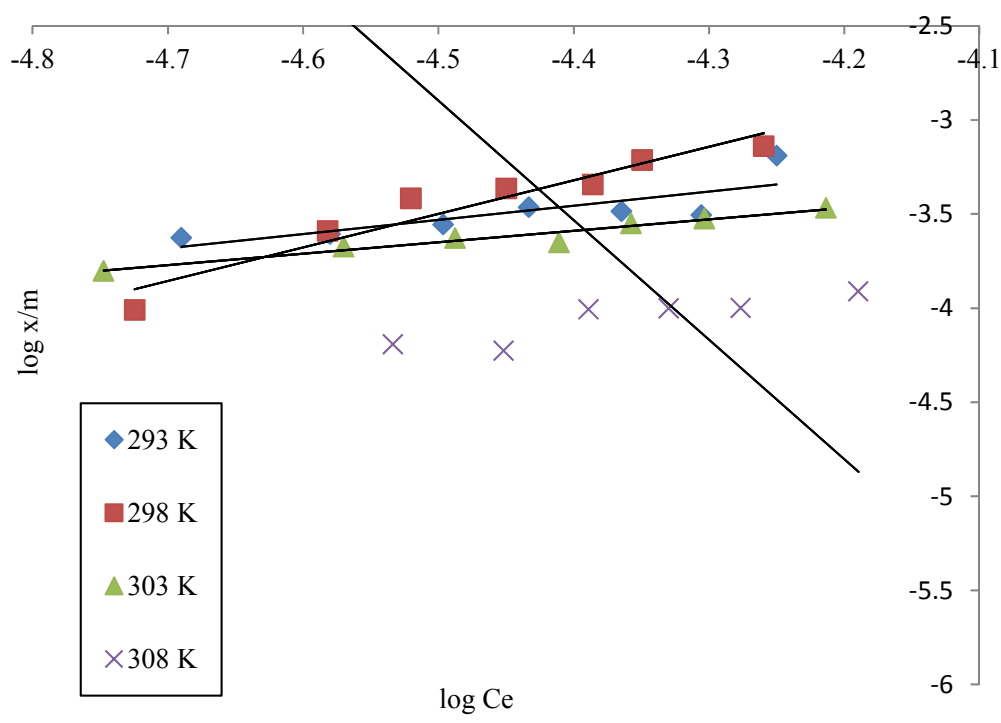

Figure 3(b). Freundlich isotherm graph for the adsorption of CBB (R-250) onto CPC

\subsubsection{D-R Adsorption Isotherm}

Dubinin-Radushkevich isotherm is commonly used to evaluate the mechanism of adsorption by using Guassian energy distribution for a heterogeneous surface (Gunay et al., 2007; Dabrowski, 2001). It is represented as;

$$
\mathrm{LnX} / \mathrm{m}=\mathrm{LnX}_{\mathrm{m}}+\mathrm{K}^{2}
$$

Where $\mathrm{X}_{\mathrm{m}}$ is the adsorbent monolayer capacity, and $\boldsymbol{\varepsilon}$ is Polanyi potential $(\varepsilon=$ amount of dye that can be adsorbed per unit weight of sorbent) which can be obtained as:

$$
\varepsilon^{2}=\operatorname{RTLn}(1+1 / \mathrm{Ce})
$$

In the above equation $\mathrm{R}$ represent the gas constant $(8.314 \mathrm{~J} / \mathrm{mol} \mathrm{K}), \mathrm{T}$ is absolute temperature $(\mathrm{K})$ and $\mathrm{Ce}$ is adsorbate equilibrium concentration (M).

The plot of $\ln X / \mathrm{m}$ versus $\hat{\varepsilon}^{2}$ is a straight line with slope $\mathrm{K}$ and intercepts $\ln \mathrm{Xm}$ as shown in Table 3 and Figure $4(\mathrm{a} \& \mathrm{~b})$. By using $\mathrm{K}$, the mean free energy of sorption is calculated as,

$$
\mathrm{E}_{\mathrm{s}}=1 /(2 \mathrm{k})^{-1 / 2}
$$


Table 3. D-R parameter for the adsorption of CBB (R-250) onto CPR \& CPC

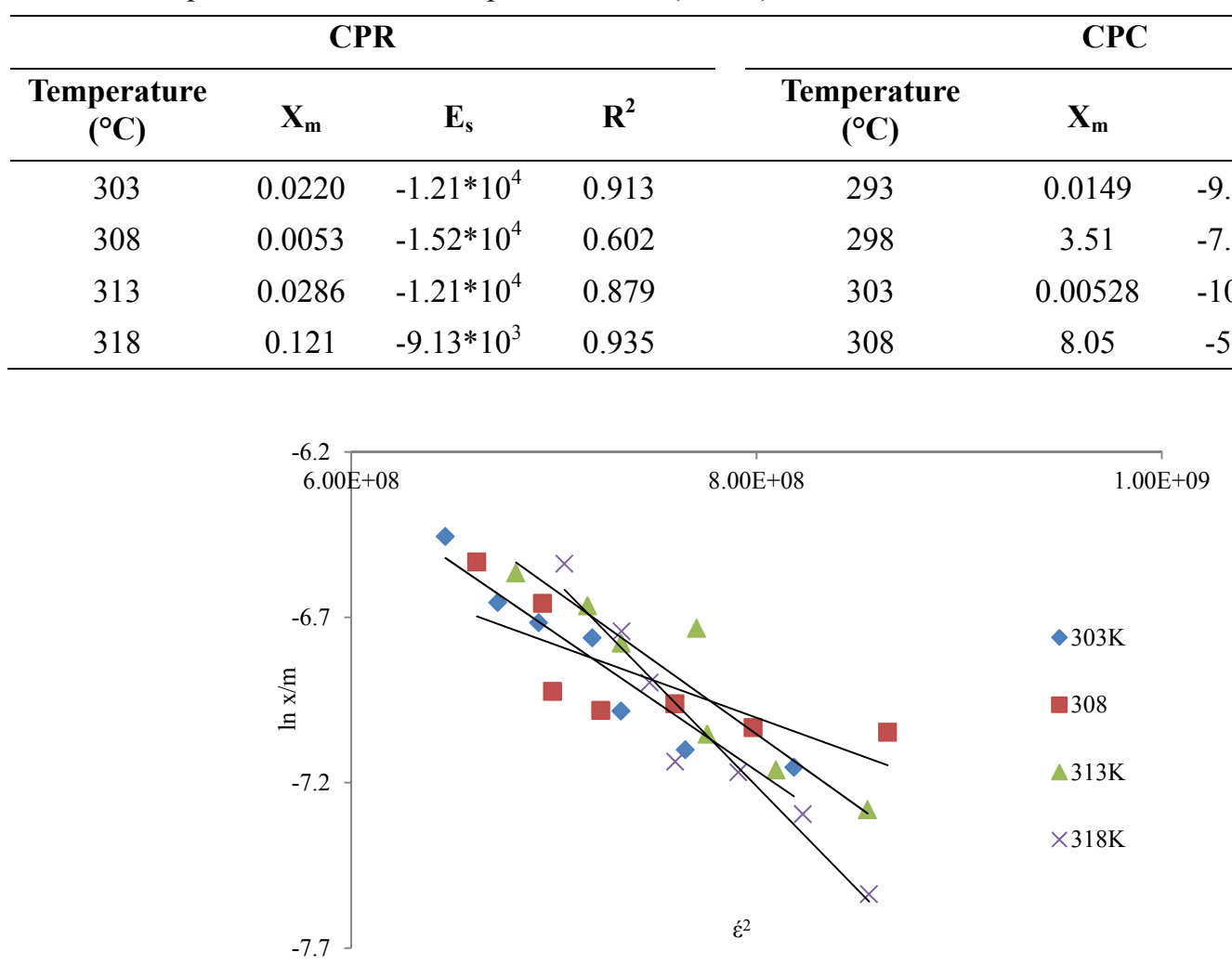

Figure 4(a). D-R isotherm graph for the adsorption of CBB (R-250) onto CPR

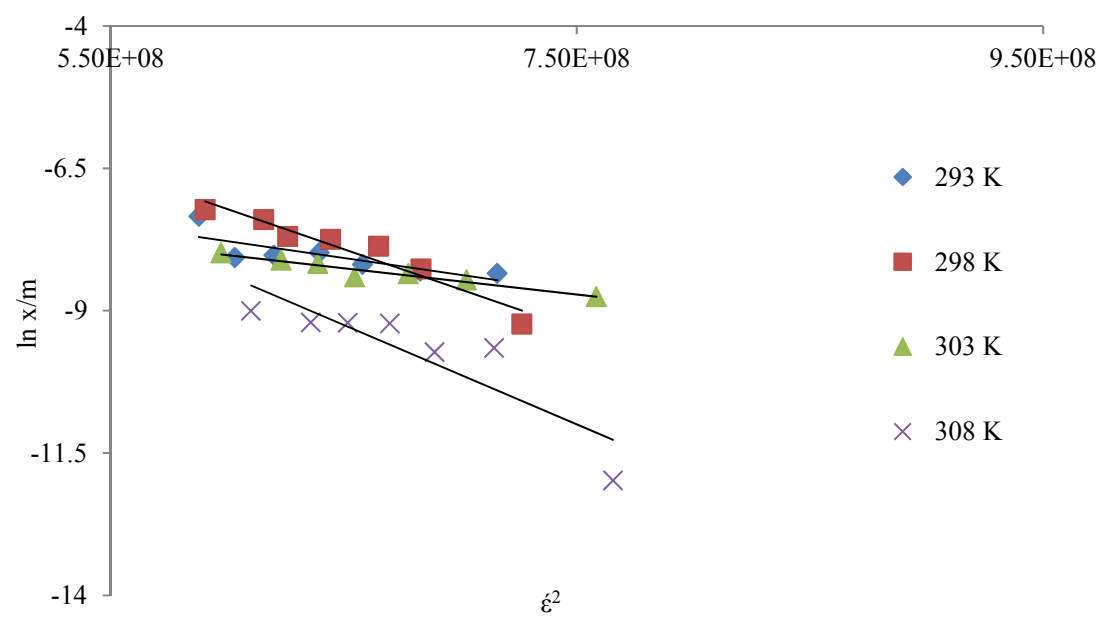

Figure 4(b). D-R isotherm graph for the adsorption of CBB (R-250) onto CPC

\subsection{Thermodynamic Parameter}

The thermodynamic quantities like free energy change $\left(\Delta \mathrm{G}^{\circ}\right)$, enthalpy $\left(\Delta \mathrm{H}^{\circ}\right)$ and entropy $\left(\Delta \mathrm{S}^{\circ}\right)$ were evaluated. These parameters were calculated by using following formulas;

$$
\begin{aligned}
& \Delta \mathrm{G}^{\circ}=\Delta \mathrm{H}^{\circ}-\mathrm{T} \Delta \mathrm{S}^{\circ} \\
& \Delta \mathrm{G}^{\circ}=-\mathrm{RTLnK} \\
& \mathrm{LnK}=-\Delta \mathrm{H}^{\circ} / \mathrm{RT}+\Delta \mathrm{S}^{\circ} / \mathrm{R}
\end{aligned}
$$


The values of enthalpy and entropy were calculated from the slope and intercept of the linear variations of $\operatorname{lnK}$ with the reciprocal of temperature $(1 / T)$ as shown in Figure $5(\mathrm{a} \& \mathrm{~b})$. The values are represented in Tables $4 \& 5$. The negative values of $\Delta G^{o}$ indicates the spontaneous nature of adsorption process whereas the positive values of $\Delta H^{o}$ confirms the endothermic nature of the system.

Table 4. Thermodynamic parameters for CBB (R-250) onto CPR

\begin{tabular}{ccccccc}
\hline Conc $(\mathbf{M})$ & $\mathbf{\Delta} \mathbf{H}^{\circ}$ & $\boldsymbol{\Delta S}^{\circ}$ & \multicolumn{5}{c}{$\mathbf{\Delta G}^{\circ}(\mathbf{K J} / \mathbf{m o l})$} \\
\cline { 5 - 8 } $\mathbf{1 0}^{\mathbf{5}}$ & $\mathbf{( K J} / \mathbf{m o l})$ & $\mathbf{( K J} / \mathbf{m o l})$ & $\mathbf{3 0 3} \mathbf{~ K}$ & $\mathbf{3 0 8 ~ K}$ & $\mathbf{3 1 3 ~ K}$ & $\mathbf{3 1 8 ~ K}$ \\
\hline 2.42 & 17.950 & 86.715 & -8.32 & -8.76 & -9.19 & -9.63 \\
3.03 & 7.782 & 54.939 & -8.86 & -9.14 & -9.41 & -9.69 \\
3.63 & 6.211 & 50.333 & -9.04 & -9.29 & -9.54 & -9.80 \\
4.24 & 7.959 & 55.945 & -8.99 & -9.27 & -9.55 & -9.83 \\
4.84 & 4.031 & 43.640 & -9.19 & -9.41 & -9.63 & -9.85 \\
5.45 & 2.542 & 38.743 & -9.20 & -9.39 & -9.58 & -9.78 \\
6.65 & 2.594 & 39.117 & -9.26 & -9.45 & -9.65 & -9.85 \\
\hline
\end{tabular}

Table 5. Thermodynamic parameters for CBB (R-250) onto CPC

\begin{tabular}{ccccccc}
\hline Conc $(\mathbf{M})$ & $\mathbf{\Delta} \mathbf{H}^{\circ}$ & $\boldsymbol{\Delta} \mathbf{S}^{\circ}$ & \multicolumn{4}{c}{$\left.\mathbf{\Delta G}^{\circ} \mathbf{( K J} / \mathbf{m o l}\right)$} \\
\cline { 5 - 7 } $\mathbf{1 0}^{\mathbf{5}}$ & $\mathbf{( K J} / \mathbf{m o l})$ & $(\mathbf{K J} / \mathbf{m o l})$ & $\mathbf{3 0 3} \mathbf{~ K}$ & $\mathbf{3 0 8 ~ K}$ & $\mathbf{3 1 3 ~ K}$ & $\mathbf{3 1 8 ~ K}$ \\
\hline 2.42 & 7.183 & 57.493 & -10.24 & -10.53 & -10.81 & -11.10 \\
3.03 & 5.361 & 51.307 & -10.19 & -10.44 & -10.70 & -10.95 \\
3.63 & 6.086 & 53.701 & -10.19 & -10.45 & -10.72 & -10.99 \\
4.24 & 5.806 & 52.812 & -10.20 & -10.46 & -10.72 & -10.99 \\
4.84 & 4.595 & 48.821 & -10.20 & -10.44 & -10.69 & -10.93 \\
5.45 & 4.565 & 48.721 & -10.20 & -10.44 & -10.68 & -10.93 \\
6.65 & 7.906 & 59.721 & -10.19 & -10.49 & -10.79 & -11.09 \\
\hline
\end{tabular}

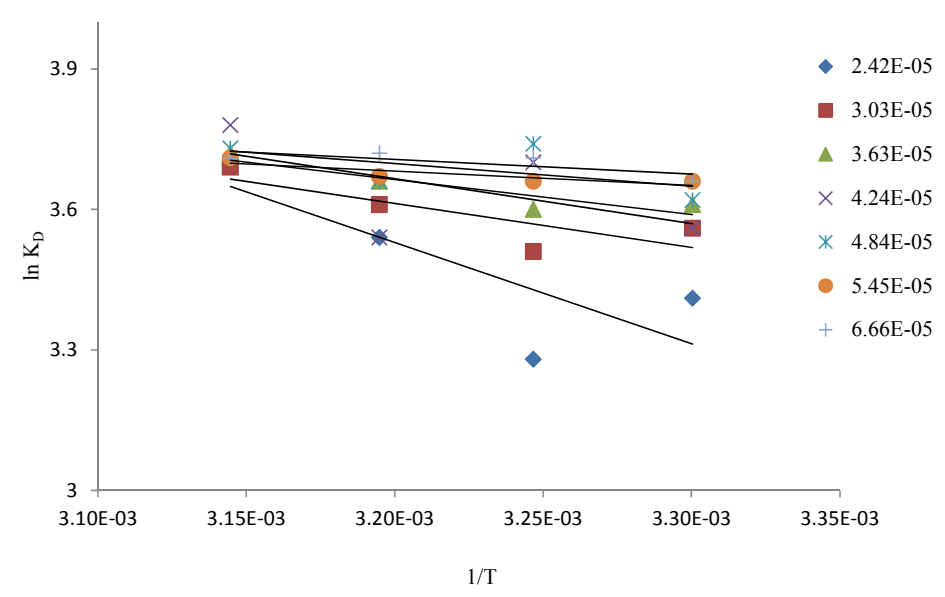

Figure 5(a). Graph of $\operatorname{Ln} K_{D}$ vs 1/T for CPR 


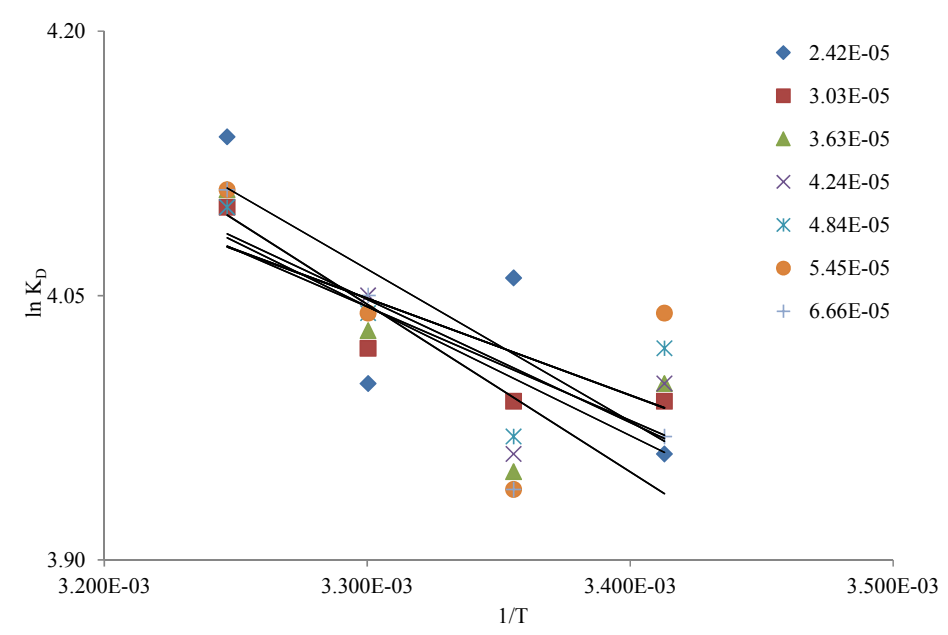

Figure 5(b). Graph of Ln $\mathrm{K}_{\mathrm{D}} \mathrm{Vs}$ 1/T for CPC

\subsection{Determination of Point of Zero Charge $\mathrm{pH}_{(p z c)}$}

The graphs of $\mathrm{pH}_{(\mathrm{pzc})}$ were plotted to determine the $\mathrm{pH}$ at which the initial and final $\mathrm{pH}$ values were equal. Final $\mathrm{pH}$ of the solutions was recorded and results were plotted with final $\mathrm{pH}$ against initial $\mathrm{pH}$ by using Table 6 as shown in Figure 6 (Vijayayakumar et al., 2012).

Table 6. Point of zero charge $\mathrm{pH}_{(\mathrm{pzc})}$ of $\mathrm{CPR}$

\begin{tabular}{cccc}
\hline Initial pH of solution & $\begin{array}{c}\text { Initial pH after adding } \\
\text { adsorbent }\end{array}$ & pH after 24 hrs & pH after 48 hrs \\
\hline 2.66 & 3.87 & 4.41 & 4.62 \\
3.42 & 5.86 & 6.12 & 6.51 \\
4.20 & 6.35 & 6.61 & 6.74 \\
10.78 & 7.10 & 6.97 & 7.22 \\
11.94 & 10.31 & 9.12 & 8.61 \\
12.97 & 12.51 & 11.41 & 10.23 \\
\hline
\end{tabular}

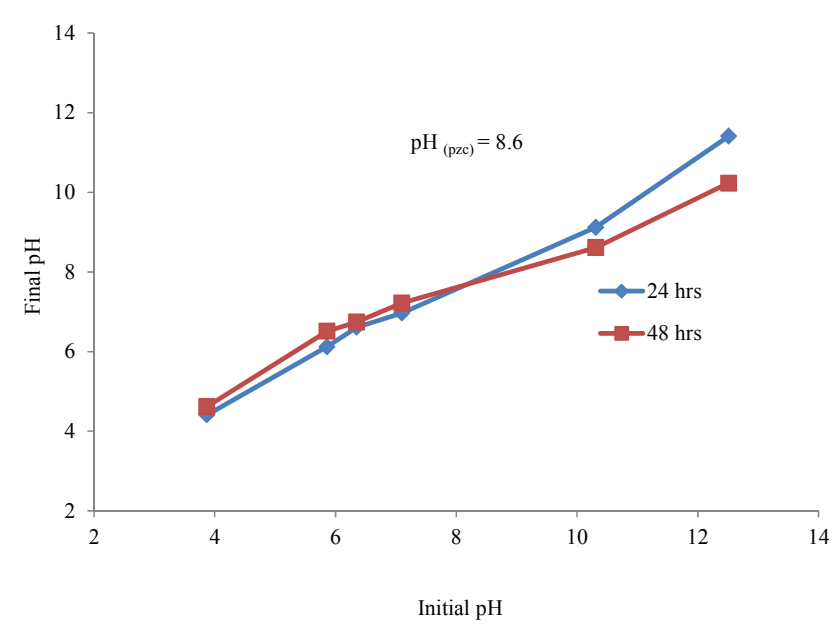

Figure 6. Graph of $\mathrm{pH}_{(\mathrm{pzc})}$ of $\mathrm{CPR}$ 


\subsection{Investigation of Photocatalytic Degradation}

The experimental results of photocatalytic degradation of Coomassie Brilliant Blue(R-250) using $\mathrm{TiO}_{2}$ were shown in Table 7. The maximum degradation of $78.21 \%$ was obtained at $4.82 \times 10^{-5} \mathrm{M}$ dye concentration after 60 minutes (Naseem \& Tahir, 2006).

Table 7. Photocatalytic degradation of CBB (R-250)

\begin{tabular}{cc} 
Concentration of dyes $=9.60 \times 10^{-5} \mathrm{M}$ \\
Volume of dye $=100 \mathrm{ml}$ \\
Photocatalyst $=\mathrm{TiO}_{2}$ \\
Temperature $=37^{\circ} \mathrm{C}$ \\
Humidity $=59.1 \%$ \\
$\lambda_{\text {max }}=591 \mathrm{~nm}$ \\
\hline \multicolumn{3}{c}{ \% Degradation } \\
\hline Time (min) & 36.46 \\
20 & 40.85 \\
30 & 66.21 \\
40 & 68.27 \\
50 & 77.50 \\
60 & 78.21 \\
\hline
\end{tabular}

\subsection{Rate Order Adsorption Kinetics}

From the optimization of shaking time the adsorption kinetics was evaluated to determine the kinetics of CBB-CPR and CBB-CPC system as shown in Figure 7. For this investigation pseudo first and second order models were applied by using the following equations (Allen et al., 2004).

$$
\begin{gathered}
\log \left(\mathrm{q}_{\mathrm{e}}-\mathrm{q}_{\mathrm{t}}\right)=\log \mathrm{q}_{\mathrm{e}}-\mathrm{k}_{1} \mathrm{t} / 2.303 \\
\mathrm{t} / \mathrm{q}_{\mathrm{t}}=1 / 2 \mathrm{k}_{2} \mathrm{qe}^{2}+1 \mathrm{t} / \mathrm{q}_{\mathrm{e}}
\end{gathered}
$$

Where $\mathrm{q}_{\mathrm{e}}$ and $\mathrm{q}_{\mathrm{t}}$ are the quantity of dye adsorbed on the adsorbent (mol/g) at equilibrium and time $\mathrm{t}, \mathrm{k}_{1}$ is the adsorption of pseudo first order rate constant $\left(\mathrm{min}^{-1}\right)$ and $\mathrm{k}_{2}$ is the adsorption of second order rate constant (mol/g.min). The pseudo second-order adsorption kinetic plots are shown in Figure 7(a \& b), which shows that it follows a pseudo-second order reaction.

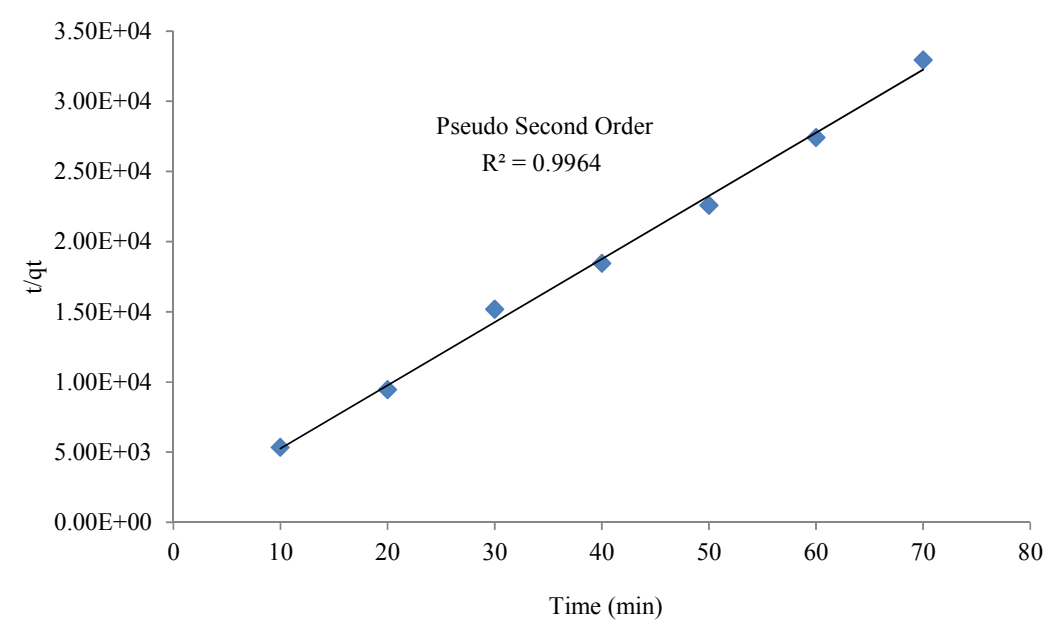

Figure 7(a). Graph of adsorption Kinetics for CPR 


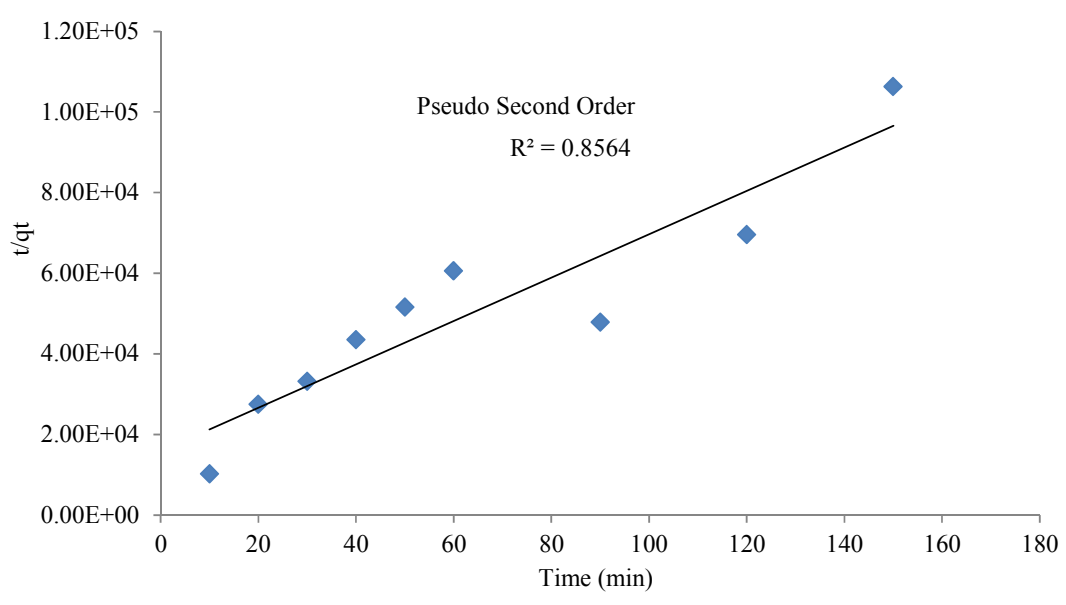

Figure 7(b). Graph of adsorption Kinetics for CPC

\section{Characterization of Coirpith CPR \& CPC}

The surface morphology of CPR CPC was carried out by adopting FTIR and SEM techniques. Fourier transform infrared spectroscopy was used to determine the variation in functional groups before and after adsorption by using IR-PRESTIGE 21 FTIR Spectrophotometer. Scanning Electron Microscopy (SEM) was used to identify the changes in the surface morphology of pre-sorbed and adsorbed CPR and CPC. The SEM was performed by using Joel JSM-6380A scanning electron microscope.

\subsection{FTIR Analysis}

FTIR spectroscopy provides structural and compositional information on the functional groups presented in the samples. The adsorption capacity of adsorbents depends upon porous nature as well as chemical reactivity of functional groups at the surface. This reactivity creates an imbalance between forces at the surface when compared to those within the body, thus leading to molecular adsorption by the Vander Waals force (Senthil Kumar et al., 2010). The adsorption spectra showed a number of absorption peaks, indicating the complex nature of coirpith. FTIR spectra of CPR and CPC are shown in Figure $8(\mathrm{a} \& \mathrm{~b})$. The tablets of coirpith were made by the binding agent i.e $\mathrm{KBr}$ which is also IR active. So the peaks due to $\mathrm{KBr}$ were appeared at 2370.51, 1654.92, 1562.34 and $1460.11 \mathrm{~cm}^{-1}$ and were slightly shifting in all the spectrums. In the spectrum of CPR pre-adsorbed a broad peak at $3452.58 \mathrm{~cm}^{-1}$ was observed due to the stretching frequency of $(\mathrm{O}-\mathrm{H})$ group. The spectrum of CPC before adsorption a broad band at $3450.65 \mathrm{~cm}^{-1}$ corresponds to the presence of hydroxyl group $(\mathrm{O}-\mathrm{H})$. The band at $2924.09 \mathrm{~cm}^{-1}$ represents the presence of alkanes. The weak band at $1373 \mathrm{~cm}^{-1}$ originates from phenol group of lignin. Aromatic skeletal vibrations at 1650,1562 and $1460 \mathrm{~cm}^{-1}$ are common for lignin samples. 


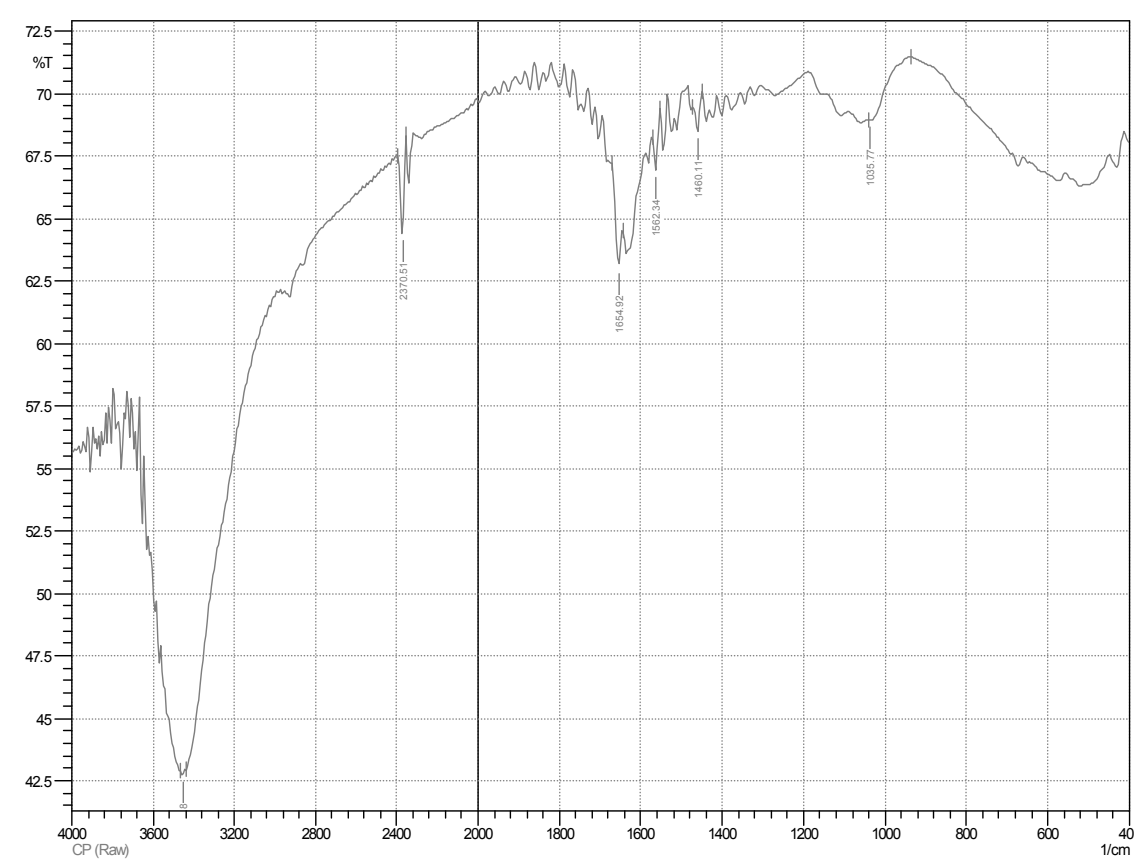

Figure 8(a). FTIR image of CPR before adsorption

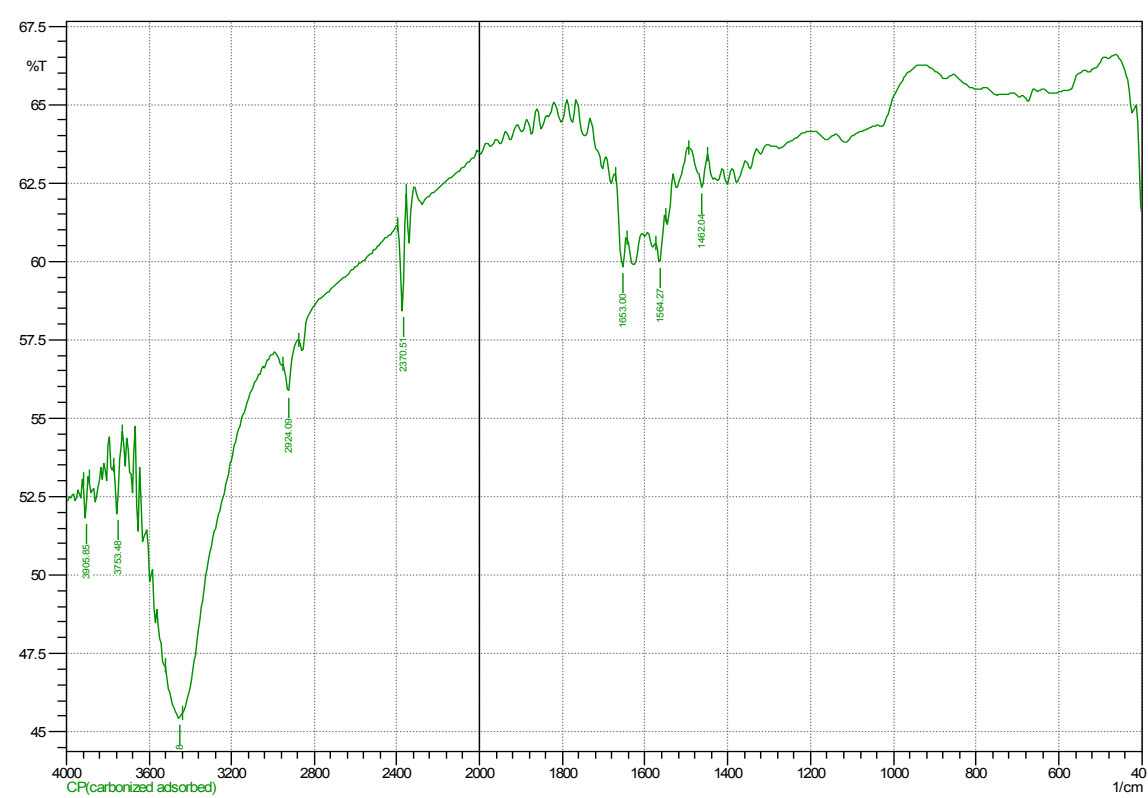

Figure 8(b). FTIR image of CPC before adsorption

\subsection{SEM Analysis}

SEM images of CPC that shows maximum \% removal were taken at different magnifications, before and after adsorption. Figure 10 shows the surface of CPC which was unsaturated and have many adsorptive sites and pores before the adsorption with CBB (R-250). There is a formation of adsorbed layer on the surface of adsorbent seems to be no active spaces are available for the further adsorption of dye as shown in Figure 9(a \& b). 


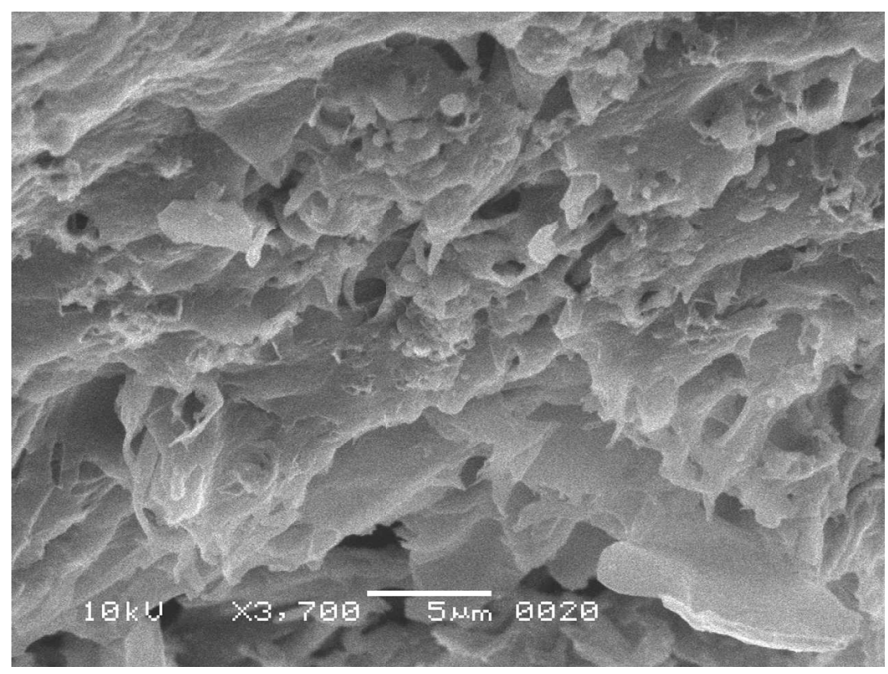

Figure 9(a). SEM image of CPC before adsorption

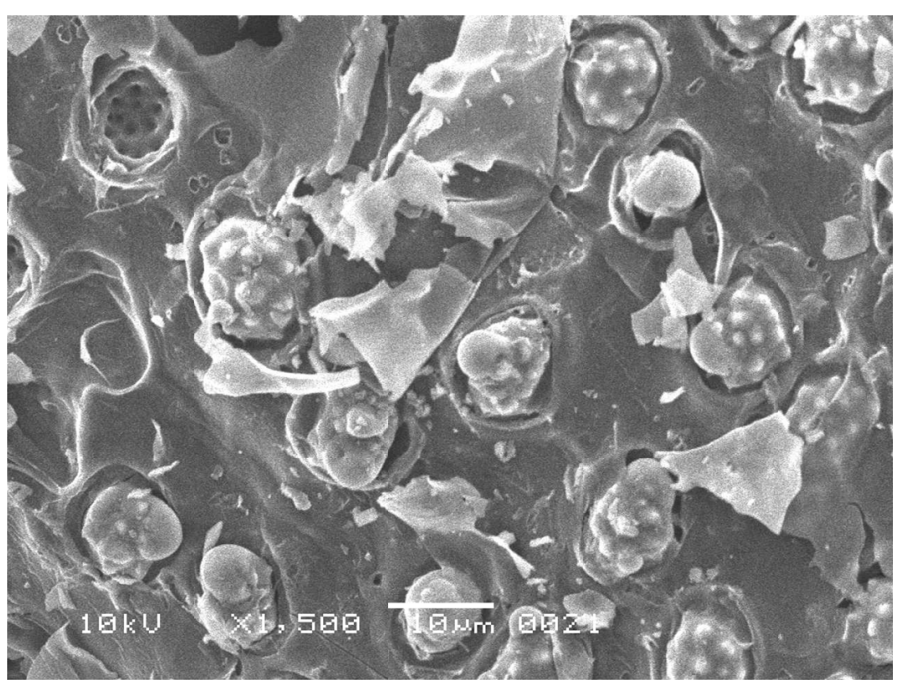

Figure 9(b). SEM image of CPC after adsorption

\section{Conclusion}

The present study shows that Coomassie Brilliant Blue (R-250) dye can be easily removed in an eco-friendly way by using coirpith (an agro waste) as an adsorbent. The percent removal of CBB (R-250) was increased with the increase in adsorbent quantity. Increase in temperature of the system elevates the adsorption rate of Coomassie Brilliant Blue (R-250). Thermodynamic analysis revealed that the adsorption process was exothermic and spontaneous in nature. By using CPR about $70 \%$ removal of dye was observed. Carbonization of coirpith enhanced the adsorption capacity as indicated by the increase uptake of CBB (R-250). The maximum of $99 \%$ dye removal was obtained by using CPC. This is because of the excess positive charges on the surface which results in increased adsorption capacity of Coomassie Brilliant Blue (R-250).

The results have revealed that the most successful fit isotherms for CPR-CBB and CPC-CBB system are Freundlich and D-R isotherm. Thermodynamic parameters like free energy $\Delta \mathrm{G}^{\circ}$, enthalpy $\Delta \mathrm{H}^{\circ}$ and entropy $\Delta \mathrm{S}^{\circ}$ were also determined. Their values shows the spontaneous, endothermic and entropy driven process. The low values of $\Delta \mathrm{H}^{\circ}$ less than $30 \mathrm{KJ} /$ mole shows that the adsorption phenomenon is particularly physisorption. Adsorption kinetics revealed that the system follow pseudo second order kinetics for CPR-CBB and CPC-CBB systems. The $\mathrm{pH}$ point zero charge investigation data shows that the adsorbent is neutralized at basic $\mathrm{pH}$. The $\%$ removal values of $\mathrm{CBB}(\mathrm{R}-250)$ by using $\mathrm{CPR}$ and $\mathrm{CPC}$ confirms that it can be utilized effectively to recycle the toxic and non-degradable dye effluent. 


\section{Acknowledgements}

We are thankful to Mr. Azhar of Instrumental Lab; Department of Chemistry, University of Karachi for assisting in FTIR facility and Mr. Yousuf Khan belonging to Central Testing Laboratory for his support, during the analysis of SEM images.

\section{References}

Aksu, Z. (2005). Application of biosorption for the removal of organic pollutants: A review. Proc. Biochem., 40, 997-1026. http://dx.doi.org/10.1016/j.procbio.2004.04.008

Aksu, Z., \& Tezer, S. (2000). Equilibrium and kinetic modeling of biosorption of Remazol Black B by Rhizopusarrhizus in a batch system: Effect of temperature. Proc. Biochem., 36, 431-439. http://dx.doi.org/10.1016/S0032-9592(00)00233-8

Annadurai, G., Juang, R. S., \& Lee, D. J. (2002). Use of cellulose-based wastes for adsorption of dyes from aqueous solutions. J. Hazard. Mater., 92, 263-274. http://dx.doi.org/10.1016/S0304-3894(02)00017-1

Azmi, W., Kumar, R., \& Banarjee, U. C. (1998). Biodegradation of triphenylmethane dyes. Enzyme and Microbial Technology, 22, 185-191. http://dx.doi.org/10.1016/S0141-0229(97)00159-2

Batzias, F. A., \& Sidiras, D. K. (2004). Dye adsorption by calcium-chloride treated beech sawdust in batch and fixed-bed systems. Journal of Hazardous Materials. B114, 167-174. http://dx.doi.org/10.1016/j.jhazmat.2004.08.014

Boparai, H. K., Joseph, M., \& O'Caroll, D. M. (2011). Kinetics and thermodynamics of cadmium ion removal by adsorption onto nano zerovalent iron particles. Journal of Hazardous Materials, 186, 458-465.

Bousher, A., Shen, X., \& Edyvean, R. G. J. (1997). Removal of colored organic matter by adsorption onto low-cost waste materials. Water Research, 31, 2084-2092. http://dx.doi.org/10.1016/S0043-1354(97)00037-7

Chial, H. J., Thomson, H. B., \& Splitterberg, A. G. (1993). A spectral study of the charge forms of Coomassie BlueG. Analytical Biochemistry, 209(2), 258-266.

Dabrowski, A. (2001). Adsorption-from theory to practice. Adv. Colloid Interface Sci., 93, 135-224.

Demirbas, E., Kobya, M., \& Konukman, A. E. S. (2008). Error analysis of equilibrium studies for the almond shell activated carbon: adsorption of Cr (VI) from aqueous solutions. Journal of Hazardous Materials, 154, 787-794.

Dubinin, M. M. (1960). The potential theory of adsorption of gases and vapors for adsorbents with energetically non-uniform surface. Chem. Rev., 60, 235-266.

Ferrero, F. (2007). Dye removal by low cost adsorbents: Hazelnut shells in comparison with wood sawdust. Journal of Hazardous Materials, 142, 144-152.

Fox, M. R. (1987). Dye-makers of Great Britain 1856-1976: A History of Chemist Companies, Products and Changes. Manchester: Imperial Chemical Industries. 38.

$\mathrm{Fu}, \mathrm{Y}$., \& Viraragahavan, T. (2002). Removal of congo red from an aqueous solution by fungus Aspergillus niger. Adv. Environ. Res., 7, 239-247. http://dx.doi.org/10.1016/S1093-0191(01)00123-X

Garg, V. K., Gupta, R., Yadav, A. B., \& Kumar, R. (2003). Dye removal from aqueous solutions by adsorption on treated sawdust. Biores.Technol, 89, 121-124. http://dx.doi.org/10.1016/S0960-8524(03)00058-0

Gautama, R. K., Mudhoo, A., Lofranoc, G., \& Chattopadhyaya, M. C. (2014). Biomass-derived biosorbents for metal ions sequestration: Adsorbent modification and activation methods and adsorbent regeneration. Journal of Environmental Chemical Engineering, 2, 239-259. http://dx.doi.org/10.1016/j.jece.2013.12.019

Gunay, A., Arslankaya, E., \& Tosun, I. (2007). Lead removal from aqueous solution by natural and pretreated clinoptilolite: adsorption equilibrium and kinetics. Journal of Hazardous Materials, 146, 362-371.

Hameed, B. H., Tan, I. A. W., \& Ahmad, A. L. (2009). Preparation of oil palm empty fruit bunch-based activated carbon for removal of 2, 4, 6-trichlorophenol: Optimization using response surface methodology. Journal of Hazardous Materials, 164, 1316-1324.

Hema, M. A. (2008). Adsorption kinetics and thermodynamics of malachite green dye onto acid activated low cost carbon. J. Appl. Sci. Environ. Manage., 12, 43-51.

Hu, W., Jian, Qiao, S. Z., Haghseresht, F., Wilson, M. A., \& Lu, G. Q. (2006). Adosrption study for the removal 
of basic red dye using bentonite. Industrial \& Engineering Chemistry Research, 45, 733-738.

Kadirvelu, K. (2000). Preparation and Characterization of Coirpith Carbon and its utilization in the treatment of metal-bearing wastewaters. Bharathiar University, Coimbatore, India. PhD thesis.

Lagergen, S. (1898). About the theory of so-called adsorption of soluble substances. Kungliga Svenska Vatenskapsakademiens. Handlinger, 24, 1-39.

Langmuir, I. (1916). The constitution and fundamental properties of solids and liquids. J. Am. Chem. Soc., 38(11), 2221-2295.

Limousin, G., Gaudet, J. P., Charlet, L., Szenknect, S., Barthes, V., \& Krimissa, M. (2007). Sorption isotherms: A review on physical bases, modeling and measurement. Appl. Geochem., 22, 249-275.

Magdy, Y. H., \& Daifullah, A. A. M. (1998). Adsorption of a basic dye from aqueous solutions onto sugar-industry-mud in two modes of operations. Waste Manage, 18, 219-226. http://dx.doi.org/10.1016/S0956-053X(98)00022-1

Malsamy, S., \& Theivarasu, C. (2012). Adsorption of Reactive Dye Using Low Cost Adsorbent: Cocoa (Theobroma Cacao) shell. World Journal of Applied Environmental Chemistry, 1, 22-29. http://dx.doi.org/10.1021/ie050889

Namasivayam, C., \& Kavitha, D. (2002). Removal of congo red from water by adsorption onto activated carbon prepared from coir pith, an agricultural waste. Dyes and Pigments, 54, 47-58. http://dx.doi.org/10.1016/S0143-7208(02)00025-6

Namasivayam, C., Kumar, M. D., Selvi, K., Vanathai, T., Yamuna, R, T., \& Begum, R. A. (2001). "Waste” coir pith-A potential biomass for the treatment of waste waters. Biomass Bioenergy, 21, 477-483.

Ncibi, M. C. (2008). Applicability of some statistical tools to predict optimum adsorption isotherm after linear and non-linear regression analysis. J. Hazard. Mater., 153, 207-212.

Ozacar, M., \& Sengil, I. A. (2005). Adsorption of metal complex dyes from aqueous solutions by pine sawdust. Biores. Technol., 96, 791-795. http://dx.doi.org/10.1016/j.biortech.2004.07.011

Pignon, H. M., Brasquet, C. F., \& Cloirec, P. L. (2003). Adsorption of dyes onto activated carbon cloths: Approach of adsorption mechanisms and coupling of ACC with ultra filtration to treat colored wastewaters. Sep. Purif. Technol., 31, 3-11. http://dx.doi.org/10.1016/S1383-5866(02)00147-8

Rangabhashiyam, S., Anu, N., Nandagopal, M, S \& Selvaraju, N. (2014). Relevance of isotherm models in biosorption of pollutants by agricultural byproducts. Journal of Environmental Chemical Engineering, 2, 398-414. http://dx.doi.org/10.1016/j.jece.2014.01.014

Ravikumar, K., Deebika, B., \& Balu, K. (2005). Decolourization of aqueous dye solutions by a novel adsorbent: Application of statistical designs and surface plots for the optimization and regression analysis. J. Hazard. Mater., 122, 75-83. http://dx.doi.org/10.1016/j.jhazmat.2005.03.008

Robinson, T., Chandran, B., \& Nigam, P. (2002). Removal of dyes from a synthetic textile dye effluent by biosorption on apple pomace and wheat straw. Water Research, 36, 2824-2830. http://dx.doi.org/10.1016/S0043-1354(01)00521-8

Robinson, T., McMullan, G., Marchant, R., \& Nigam, P. (2001). Remediation of dyes in textile effluent: A critical review on current treatment technologies with a proposed alternative. Bioresource Technol., 77, 247-255. http://dx.doi.org/10.1016/S0960-8524(00)00080-8

Senthil Kumar, P., Ramalingam, S., Senthamarai, C., Niranjanaa, M., Vijayalakshmi, P., \& Sivanesam, S. (2010). Adsorption of dye from aqueous solution by cashew nut shell: Studies on equilibrium isotherm, kinetics and thermodynamics of interactions. Desalination, 261, 52-60.

Sun, Q., \& Yang, L. (2003). The adsorption of basic dyes from aqueous solution on modified peat-resin particle. Water Research, 37, 1535-1544. http://dx.doi.org/10.1016/S0043-1354(02)00520-1

Tahir, H., Sultan. M., \& Jahanzeb, Q. (2009). Remediation of azo dyes by using household black tea as an adsorbent. Afr. J. Biotechnol, 8, 3584-3589.

Tan, I. A. W., Ahmad, A. L., \& Hameed, B. H. (2008). Adsorption of basic dye on high-surface-area activated carbon prepared from coconut husk: Equilibrium, kinetic and thermodynamic studies. Journal of Hazardous Materials, 154, 337-346.

UCUN, H. (2011). Equilibrium, Thermodynamic and kinetics of reactive black 5 biosorption on loquat 
(Eriyobotryajaponica) Seed. Scientific Research and Essays, 6, 4113-4124.

Vijayakumar, G., Tamilarasan, R., \& Dharminderakumar, M. (2012). Adsorption, Kinetic, Equilibrium and Thermodynemics studies on the removal of basic dye rhodamine-B from aqueous solution by the use of natural adsorbent perlite. J. Master. Environ. Sci., 3, 157-170.

Vijayaraghavan, K., Padmesh, T. V. N., Palanivelu, K., \& Velan, M. (2006). Biosorption of nickel (II) ions onto Sargassumwightii: Application of two-parameter and three parameter isotherm models. Journal of Hazardous Materials, B133, 304-308.

Vijayaraghavan, K., \& Yun, Y. S. (2008). Bacterial biosorbents and biosorption. Biotechnol. Adv., 26, $266-291$.

Wu, F. C., \& Tseng, R. L. (2008). High adsorption capacity NaOH-activated carbon for dye removal from aqueous solution. Journal of Hazardous Materials, 152, 1256-1267. http://dx.doi.org/10.1016/j.jhazmat.2007.07.109

\section{Copyrights}

Copyright for this article is retained by the author(s), with first publication rights granted to the journal.

This is an open-access article distributed under the terms and conditions of the Creative Commons Attribution license (http://creativecommons.org/licenses/by/3.0/). 